\title{
EDITORIAL
}

\section{Pathology, Publishing, and a Pandemic}

Emily H. Essex, Managing Editor, ${ }^{*}$ Chhavi Chauhan, Director of Scientific Outreach, ${ }^{*}$ and Martha B. Furie, Editor-in-Chief ${ }^{\dagger}$

From the American Society for Investigative Pathology, ${ }^{*}$ Rockville, Maryland; and the Department of Pathology, ${ }^{\dagger}$ Stony Brook University, Stony Brook, New York

As scientists, we are all aware of past pandemics and the great toll that they have taken in terms of mortality. Many of us also are knowledgeable about the biological forces that drive global outbreaks of infectious diseases. But the overwhelming impact of pandemics on every aspect of life, from the trivial to the profound, was hard to appreciate until we found ourselves in the midst of one. Like every institution worldwide, The American Journal of Pathology (AJP) had to adapt rapidly to an unimaginable and constantly shifting new landscape. The editorial office of $A J P$ made the switch to remote work in midMarch when the coronavirus disease 2019 (COVID-19) pandemic reached its Maryland location. From a logistical standpoint, a work-from-home quarantine had little impact on the daily functions of AJP. The Journal is fortunate to operate through Editorial Manager, an entirely web-based platform for manuscript submission, review, and production processes. Moreover, employees of the editorial office were already equipped with home offices and remote access to the servers of $A J P$ 's parent organization, the American Society for Investigative Pathology (ASIP).

However, $A J P$ functions in a global environment, which led to a temporary challenge in terms of producing final versions of articles. Although AJP's main contacts at its publisher, Elsevier, are based in the United States and readily able to work from home, the company that is contracted to handle the typesetting for the Journal, located in India, needed time to adjust as protocols for operating remotely were not previously part of the workflow. This minor delay for adjustment lasted roughly 2 weeks and impacted only the proof process and release of the final versions of manuscripts. Articles were still publishing online as Articles in Press (https://ajp.amjpathol. org/inpress, last accessed October 16, 2020), so new content

Accepted for publication October 30, 2020.

Disclosures: None declared.

Address correspondence to Emily H. Essex, American Society for Investigative Pathology, 1801 Rockville Pike, Ste. 350, Rockville, MD 20852. E-mail: eessex@ asip.org. remained continually available. After the initial delay, print publication of the journal was able to catch up and was back on schedule within 2 months.

$A J P$ also began to feel the impact of global closures in other ways. As work in laboratories all over the world slowed, halted, or refocused on COVID-19, submissions to the Journal began to drop. Historically, AJP has received around $45 \%$ of its new manuscripts from Asia, and, as closures were enacted, submissions coming from Japan and mainland China decreased significantly. The effect then rippled out to Europe and the Americas as the pandemic spread. Noticing the decline in submissions, the AJP staff and editors were proactive in reaching out to the ASIP membership, as well as the Journal's social media following, to encourage writing of manuscripts during forced absences from the bench. A call for papers was sent from the Editor-in-Chief in April and resulted in over a dozen proposals for Review articles from ASIP members, as well as several submissions of new research articles.

AJP's publishing team at Elsevier also has assisted in recruitment of new manuscripts. Elsevier quickly set up an online coronavirus information center (https://www.elsevier. com/connect/coronavirus-information-center, last accessed October 16, 2020) that comprises a variety of resources, including journals with active calls for papers related to COVID-19. AJP initiated a generic call for such manuscripts and was included in this initiative. The call for papers also was placed on AJP's website (https://ajp.amjpathol.org) and is still active. Moreover, Elsevier provides all readers with free access to COVID-19-related articles. Collectively, the efforts of Elsevier and AJP's staff and editors, along with a global community adapting to working during a pandemic, yielded a return to normal submission numbers through the summer. Encouragingly, a single month tally of new manuscripts in June was the highest since November 2018. Total submissions for 2020 ended up nearly on par with 2019, and the staff and editors continue their outreach to solicit new content both related and unrelated to COVID-19. 
With respect to combating the pandemic, $A J P$ 's editors and staff are proud to have expedited publication of articles that showcase the contributions that pathologists have made to this effort. ${ }^{1-7}$ For example, this month's issue contains a timely Review article by Gustine and Jones ${ }^{7}$ that discusses hyperinflammation in COVID-19 and provides mechanistic insights to target severe acute respiratory syndrome coronavirus 2 and manage disease manifestations. In the November issue, AJP published a Biological Perspectives article centered on universal autopsy precautions for patients with infectious diseases ${ }^{5}$; this highly relevant piece was authored by Michael Kritselis and Daniel Remick, a past president of ASIP. And two recent research articles by James Musser, another former ASIP president, and his colleagues on the efficacy of convalescent plasma for treating COVID-19 patients received extraordinary attention from the scientific community and lay media. ${ }^{1,6}$ Notably, results of this work contributed to the Food and Drug Administration's decision to grant Emergency Use Authorization for plasma therapy (https://www.fda.gov/media/142386/ download, last accessed October 19, 2020).

$A J P$ 's editors and staff also are mindful of the challenges that authors have grappled with and continue to face. In their responses to reviewers' calls for additional experiments, authors have been encouraged to indicate if laboratory closures or restrictions impact their ability to perform such studies. In turn, reviewers have been asked to consider limiting suggestions for additional experimentation to those that are essential to the integrity of the work. Indeed, this is a consideration that the editors intend to recommend even post-pandemic; Hidde Ploegh's 2011 column in Nature offers a compelling plea for reviewers to confine their evaluations to what the manuscript in hand contains. ${ }^{8}$

Apart from the COVID-19 pandemic, AJP has been advancing scientific research in each of its topic categories by routinely publishing informative, educational Reviews and Mini-Reviews authored by thought leaders. In 2020, 24 such articles appeared in its pages. AJP also featured pieces from various ASIP award recipients, including a fascinating, engaging Review article on IL-2 written by ASIP GoldHeaded Cane Award recipient Abul K. Abbas. ${ }^{9}$ In addition, $A J P$ has featured one to two thematic issues every year for the past several years, and 2020 was no exception. A Theme Issue on the glycocalyx in human diseases, orchestrated by AJP Associate Editor Michael Goligorsky, ${ }^{10}$ appeared in April. Given the success of these topical efforts, three timely Theme Issues are in progress for publication in 2021. These issues will be entitled Artificial Intelligence and Deep Learning in Pathology, Role of the Tumor Microenvironment in Breast Cancer, and Small Blood Vessel Disease in the Brain.

Although 2020 has presented AJP with many challenges to navigate, there is exciting news to announce for 2021 . Beginning with this January issue, page charges for those who are in the ASIP Regular member category will be significantly reduced. Corresponding or co-corresponding authors who are Regular members will be charged $\$ 99$ per page, down from the previous member rate of $\$ 185$ per page. Open Access charges also have been decreased substantially for both ASIP members and nonmembers. Additional information on the benefits of membership in ASIP, along with the link to join, is available online here: https:// www.asip.org/membership-community/member-benefits.

Through the dedication and hard work of its staff, editors, and production team, $A J P$ is poised to successfully weather the pandemic. We greatly appreciate the patience and flexibility of the authors and reviewers who have supported the Journal throughout this difficult time. We continue to welcome manuscripts related to the molecular and cellular basis of disease from all authors; these submissions can be processed online here: https://www.editorialmanager.com/ ajpa/default.aspx. And we are delighted that the advantages of an ASIP Regular membership now include a nearly $50 \%$ cut in page charges, a benefit that we hope will inspire submissions of new content from our ASIP member authors as we move forward into 2021 .

\section{References}

1. Salazar E, Perez KK, Ashraf M, Chen J, Castillo B, Christensen PA Eubank T, Bernard DW, Eagar TN, Long SW, Subedi S, Olsen RJ, Leveque C, Schwartz MR, Dey M, Chavez-East C, Rogers J, Shehabeldin A, Joseph D, Williams G, Thomas K, Masud F, Talley C, Dlouhy KG, Lopez BV, Hampton C, Lavinder J, Gollihar JD, Maranhao AC, Ippolito GC, Saavedra MO, Cantu CC, Yerramilli P, Pruitt L, Musser JM: Treatment of coronavirus disease 2019 (COVID-19) patients with convalescent plasma. Am J Pathol 2020, 190:1680-1690

2. Hammock BD, Wang W, Gilligan MM, Panigrahy D: Eicosanoids: the overlooked storm in coronavirus disease 2019 (COVID 19)? Am J Pathol 2020, 190:1782-1788

3. Argyropoulos KV, Serrano A, Hu J, Black M, Feng X, Shen G, Call M, Kim MJ, Lytle A, Belovarac B, Vougiouklakis T, Lin LH, Moran U, Heguy A, Troxel A, Snuderl M, Osman I, Cotzia P, Jour G: Association of initial viral load in severe acute respiratory syndrome coronavirus 2 (SARS-CoV-2) patients with outcome and symptoms. Am J Pathol 2020, 190:1881-1887

4. Zheng H, Cao JJ: Angiotensin-converting enzyme gene polymorphism and severe lung injury in patients with coronavirus disease 2019. Am J Pathol 2020, 190:2013-2017

5. Kritselis M, Remick DG: Universal precautions provide appropriate protection during autopsies of patients with infectious diseases. Am J Pathol 2020, 190:2180-2184

6. Salazar E, Christensen PA, Graviss EA, Nguyen DT, Castillo B, Chen J, Lopez BV, Eagar TN, Yi X, Zhao P, Rogers J, Shehabeldin A, Joseph D, Leveque C, Olsen RJ, Bernard DW, Gollihar J, Musser JM: Treatment of coronavirus disease 2019 patients with convalescent plasma reveals a signal of significantly decreased mortality. Am J Pathol 2020, 190: 2290-2303

7. Gustine JN, Jones D: Immunopathology of hyperinflammation in COVID-19. Am J Pathol 2021, 191:4-17

8. Ploegh H: End the wasteful tyranny of reviewer experiments. Nature 2011, 472:391

9. Abbas AK: The surprising story of IL-2: from experimental models to clinical application. Am J Pathol 2020, 190:1776-1781

10. Goligorsky MS: The cell "coat of many colors." Am J Pathol 2020, 190:728-731 